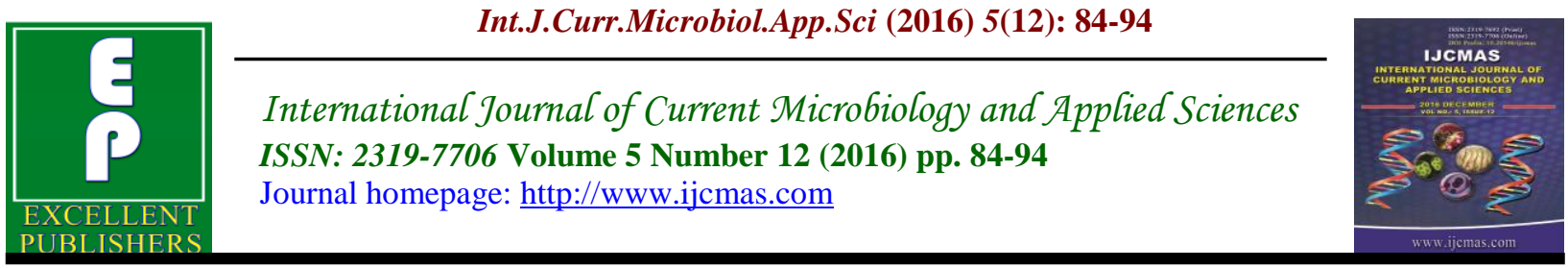

Original Research Article

http://dx.doi.org/10.20546/ijcmas.2016.512.010

\title{
Intercrops Influence Mycorrhizal Symbiosis Development, Growth and Nutrient Uptake of Banana
}

\author{
Marie Solange Mandou ${ }^{1}$, Souleymanou Adamou ${ }^{2}$, Dieudonné Nwaga $^{3}$, \\ and François-Xavier Etoa ${ }^{3}$
}

${ }^{1}$ Department of Agriculture, Faculty of Agronomy and agricultural Sciences, the University of Dschang, P.O. Box 222 Dschang, Cameroon

${ }^{2}$ Laboratory of Soil Microbiology, Biotechnology Centre, University of Yaoundé I P. O. Box

3851 Messa, Yaoundé, Cameroon

${ }^{3}$ Department of Microbiology, Faculty of Science, University of Yaoundé I. P.O. Box 812

Yaoundé, Cameroon

*Corresponding author

\begin{tabular}{|c|c|}
\hline & B S T R A C T \\
\hline Keywords & \multirow{4}{*}{$\begin{array}{l}\text { A greenhouse study was conducted to investigate the impact of intercrops on the } \\
\text { mycorrhizal symbiosis development, growth and nutrient uptake of banana. } \\
\text { Groundnut and sweet potato were raised as intercrops with banana. The banana in } \\
\text { the intercropping system showed higher root colonization in terms of hyphae, } \\
\text { Arbuscules and vesicules whatever the crop associated. Intercropping banana with } \\
\text { groundnut did not affect banana growth. Contrarily, intercropping banana with } \\
\text { sweet potato showed negative effects on banana growth. The concentration of } \\
\text { minerals in banana shoot was affected by intercrops species. There was no } \\
\text { interspecific competition between banana and groundnut for } \mathrm{N} \text { and } \mathrm{K} \text { uptake. } \\
\text { However, P was negatively affected in banana shoot. N and P concentration was } \\
\text { reduced in banana co-cultivated with sweet potato. These results show that } \\
\text { intercropping can be used to improve mycorrhizal symbiosis activity in banana } \\
\text { plantations. Moreover the choice of companion crops is the key for successful } \\
\text { application of the system. }\end{array}$} \\
\hline $\begin{array}{l}\text { growth, } \\
\text { nutrient uptake, } \\
\text { banana. }\end{array}$ & \\
\hline Artic & \\
\hline & \\
\hline
\end{tabular}

\section{Introduction}

Intercropping is the simultaneous cultivation of more than one crop species on the same piece of land. The system is based on the management of plant interactions to maximize growth and productivity (Willey, 1979a). Scientific investigations to evaluate this system have reported many advantages associated with intercropping such as risk minimization, effective use of available resources, efficient use of labour, food security, pest control (Ouma and Jeruto, 2010; Pelzer et al., 2014; Nasri et al., 2014). Intercropping may specifically facilitate the propagation of some beneficial microorganisms such as arbuscular mycorrhizal fungi (AMF) (Cruz et al., 2000). 
Arbuscular mycorrhizal fungi (AMF) belong to the Phylum Glomeromycota (Schüssler, 2001). They form symbiotic associations with more than $80 \%$ of terrestrial plants (Fortin et al., 2008). Benefits of AMF to plants include promoting water and nutrient uptake especially P (Hodge et al., 2010). The fungi in return benefit from the supply of carbohydrates derived from photosynthesis. In addition these symbiotic fungi increase plant resistance to biotic and abiotic stresses (Gianinazzi et al., 2010; Vos et al., 2012 b). For full benefits of AM fungi to be realized, there is need to maintain a high and viable natural populations of AM fungi in the soil to increase the chances of root colonization. Hence two strategies may be adopted to increase the density of AMF in the soil: indirectly by favoring the effective indigenous AMF population through adequate cultural practices, and directly through soil or plant inoculation with selected strains of AMF. In both cases the determination of cultural practices beneficial to mycorrhizal association is of high importance (Sieverding and Leihner, 1984).

Intercropping has been shown to have the potential to maintain high and viable natural population of AMF in soils due to higher plant diversity thus optimum root colonization. Harinikumar et al., (1990) observed that intercropping maize and soybean stimulated the proliferation of AMF in both plant species as compared to monocropping system. Ishii et al., (1996) demonstrated that intercropping of Citrus reticulate (satsuma mandarin) and sod culture using Paspalum notatum Flugge (Bahiagrass) improved mycorrhizal colonization in the roots of satsuma mandarin compared to monoculture of this crop. The apparent low specificity observed in fungus - plant pairs (Smith and Read, 2008) indicated that the AMF hyphae distributed in the soil may connect several plant species and then promote a network system among plants. The interconnecting networks may act as conduits for interplant transfer of resources (Bücking and Kafle, 2015).

Banana is a major staple food for millions of people in the sub-Saharan Africa. Most of its production $(80 \%)$ is conducted by small scale farmers. Primarily practiced by small holders for food security and additive income, intercropping is actually common due to increasing land pressure in most of the production regions (Lemeilleur et al. 2003). Also the usual spacing of $3 \mathrm{~m}$ by $3 \mathrm{~m}$ facilitated this system over monocropping (Ouma, 2009). Hence bananas are usually intercropped with food crops (bean, groundnut, sweet potato or vegetables), fruit trees and other cash crops (Cocoa, coffee, palm tree). Several studies have been conducted to investigate the effect of various intercrops on the performance of bananas with respect to yield, growth and pest incidences (McIntyre et al., 2001; De Waele et al., 2006). However, little attention was paid on the effect of intercropping on the mycorrhizal symbiosis of banana. Banana has been shown to be mycorrhizalresponsive. The growth and development of banana was improved in the presence of several AMF strains (Declerck et al., 1994). Van der Veken et al., (2008) demonstrated that the majority of banana intercrops were more or less compatible to AMF and hence could increase or maintain AMF rhizophere population. Groundnut (Arachis hypogeae L.) and sweet potato (Ipomoea batatas (L) Lam.) were regularly found as intercrops in most of the banana-based cropping systems in Cameroon.

The aim of the present study was to investigate the influence of intercropping banana with groundnut or sweet potato on 
the development of mycorrhizal symbiosis, growth and nutrient uptake of banana plantlets under greenhouse conditions. The study is based on the hypothesis that intercropping enhances mycorrhizal root colonization and subsequently growth and nutrient uptake of banana plantlets.

\section{Materials and Methods}

\section{Biological material}

Micropropagated banana plantlets (Musa accuminata. cv. Grande Naine) were obtained from Vitropic (Montpellier, France).

An unknown variety of sweet potato (Ipomea batatas (L) Lam) was obtained from the market in Belgium. Tubers were washed with tap water and surface-sterilized in $1 \%$ sodium hypochlorite and rinsed with several changes of sterile (121 C for $15 \mathrm{~min}$ ) distilled water. They were then germinated on volcanic ash (DCM, DE Ceuster Meststoffen N.V/S.A Belgium). Plantlets of about $10 \mathrm{~cm}$ were obtained after 8 weeks of culture.

Groundnut seeds (Arachis hypogeae L.) cv A26 was provided by the National institute of agronomic research for development of Cameroun, IRAD, Njombé, Cameroun. Seeds were surface-sterilized by immersion in sodium hypochlorite $(5 \%)$ for $5 \mathrm{~min}$, rinsed in sterile (121 $\mathrm{C}$ for $15 \mathrm{~min}$ ) distilled water before sowing in boxes.

The AMF strain used to produce inoculum was Rhizophagus rregulariss MUCL 41883, supplied by GINCO (http://www. mycorrhiza.be/ginco-bel/index.php). $R$. irregularis was previously classified as Glomus intraradices N.C. Schenck \& G.S.Sm. The inoculum was produced on leek plants (Allium porrum) for four months.
Mixture of spores, hyphae and colonized leek roots $(0.5 \mathrm{~cm}$ length) were used. The concentration was about 120 propagules per $\mathrm{g}$ of inoculum.

\section{Inoculation}

Banana plantlets were weaned in $125 \mathrm{ml}$ pots two weeks before the inoculation with AMF. They were washed with tap water to remove residues of agar from the roots and were transferred to pots containing sterilized ( $2 \mathrm{x} 1$ hour at $121^{\circ} \mathrm{C}$ ) volcanic ash. Twelve grams of the AMF inoculum were spread as a layer between two layers of sterilized volcanic ash in each box before transferring plantlets into the box.

\section{Experimental design}

The experiment was conducted in a greenhouse (photoperiod $12 \mathrm{~h}$, average temperature $24-28^{\circ} \mathrm{C}$, and $70-80 \%$ relative humidity) in boxes $(20 \times 10 \times 10$ $\mathrm{cm})$.

The design was completely randomized with ten replicates. Three treatments were considered: banana monoculture, bananagroundnut and banana-sweet potato combinations. The number of banana plants was 2 in monoculture. The ration of banana: intercrop was $1: 1$ in the intercropping treatment. Monoculture of groundnut and sweet potato were also considered.

Two weeks old weaned banana plantlets were transferred to the boxes. The plants were separated with a distance of $10 \mathrm{~cm}$. Groundnut seeds were sown at the transfer time. Sweet potato plantlets were separated from the growing tubers, and their height was homogenized for about $10 \mathrm{~cm}$ by cutting the plantlet apex. The plants were fertilized at planting by $2 \mathrm{~g}$ of osmocote ((NPK 10-11-18), Scott Benelux bvba/sprl, 
Belgium) per box and were watered when needed.

\section{Variables assessment}

All the plants were harvested 6 weeks after planting. Roots were washed with tap water before the determination of biomasses. Shoot fresh and dry weight and root fresh weight were measured for each plant. The shoot dry weight was determined after drying the leaves, pseudostem and cormus for 72 hours in an oven at $60^{\circ} \mathrm{C}$. The banana height was measured from the top of the rhizome to the crossing point of the two unfolded leaves. The leaf area was calculated with the measures of the length (L) and the width (W) of the last unfolded leaf $(\mathrm{LxWx} 0,7)$. The diameter of pseudostem was measured at $2 \mathrm{~cm}$ from the base of the plant using the vernier calliper. Only root fresh weight, shoot fresh weight and shoot dry weight were considered in intercrops.

Mycorrhizal root colonization was determined on an aliquot root sample of all the plant species (banana, groundnut, sweet potato). Roots were clarified using $10 \%$ $\mathrm{KOH}$ overnight at room temperature. They were washed several times with deionized water and soaked in alkaline 3, $5 \% \mathrm{H}_{2} \mathrm{O}_{2}$ for 30 min (Koske and Gemma, 1989). The roots were subsequently stained at room temperature for $45 \mathrm{~min}$ with a solution of blue ink (Parker ${ }^{\mathrm{P}}$ Quink $\left.{ }^{\circledR}\right)$ diluted in $1 \%$ $\mathrm{HCl}$ at 1:50 proportions (Vierheilig et al., 1998a). Root colonization was assessed by the method of McGonigle et al., (1990) to determine the number of arbuscules, vesicles and hyphae.

The mineral nutrients were assessed only for banana. The plant shoots were ground to < $1 \mathrm{~mm}$ particle size and were analysed for $\mathrm{N}$, $\mathrm{P}, \mathrm{K}, \mathrm{Ca}, \mathrm{Mg}, \mathrm{Mn}$. Mineralization was done according to the method described by Chao and Sanzolone (1992). P, K, Ca, Mg and Mn concentrations were determined by atomic absorption spectrophotometer and $\mathrm{N}$ with an analyzer CN Thermo Finnigan.

\section{Statistical analysis}

Statistical analysis was performed with the statistical software Statistica. Data were analyzed by ANOVA and means were separated by HDS Tukey test $(\mathrm{P} \leq 0.05)$. Prior to analysis, data for percentage mycorrhizal root colonization was arcsin $(\mathrm{x} / 100)$ transformed.

\section{Results and Discussion}

\section{Mycorrhizal root colonization response in species combination}

Intercropping significantly affected the root colonization of banana by Rhizophagus intraradices irrespective of the plant species combination. The percentage of hyphae was $75 \%$ in intercropped banana as compared to monoculture with $58 \%$. There was no significant difference between hyphae root colonization of banana plantlets under groundnut and sweet potato intercrops. The proportion of arbuscules was also higher in banana intercropping system $60 \%$ and 46, 8 $\%$ respectively for groundnut and sweet potato combinations) compared to monosystem $(30,3 \%)$ although non significative in the case of sweet potato combination (Table 1).

The plant combinations increase the proportion of vesicles in banana root, although non significative in comparison with monoculture.

Groundnut and sweet potato showed significant higher root colonization in the combination with banana as compared to 
that obtained in monoculture. The hyphae colonization was $52,7 \%$ and $46,2 \%$ respectively for groundnut and sweet potato in an intercropping system in comparison to monoculture $(38,7 \%$ and $34 \%$ respectively for groundnut and sweet potato) (Table 1). Arbuscules and vesicles showed similar trends. No significant differences were noted in root colonization of groundnut and sweet potato in respect on the hyphae, arbuscules and vesicules.

\section{Plant growth response in species combination}

The effect of cropping banana with other plant species on the plant growth parameters was variable according to the combination of crop species. Sweet potato significantly reduced the growth of banana. The relative reduction of growth was about 23\%, 26\% and $44 \%$ respectively for plant height, diameter of pseudostem and leaf area (Table 2). Root fresh weight, shoot fresh weight and shoot dry weight showed similar trends with a decrease of approximately $40 \%, 55$ $\%$ and $45 \%$ respectively. In contrast, groundnut has shown to be more compatible in combination with banana. Although root fresh weight of banana plantlets significantly decreased in banana-groundnut combination, no significant differences were observed in shoot fresh and dry weight for both banana monoculture and banana groundnut treatment (Table 2).

Groundnut and sweet potato were not significantly affected by crop combination. No significant difference was observed in root fresh weight, shoot fresh and dry weight when they were cropped with banana as compared to monoculture (Table 3).

\section{Shoot nutrient content}

Considering the nutrient content in banana shoots, the effect of intercropping is variable, depending on the intercrop and nutrient needs of each plant species (Table 4). $\mathrm{Ca}$ and $\mathrm{Mg}$ concentrations were not affected by crop combination, irrespective to species. The banana-groundnut pairs showed no difference in $\mathrm{N}$ and $\mathrm{K}$ concentration in banana shoot as compared to that obtained in monoculture. However the $\mathrm{P}$ content in the banana shoot significantly decreased in the presence of groundnut in comparison to monoculture. On the other hand, by combining sweet potato and banana, the $\mathrm{N}$ and $\mathrm{K}$ concentration in banana were significantly reduced over monoculture. However no effects were observed for $\mathrm{P}$ due to this combination. The Mn content in the banana shoots was significantly reduced by species combination.

In this study, we showed that growing banana with food crop species stimulated the colonization of roots by AMF. Plant root colonization was higher in the banana intercrops - pairs than in monoculture treatment probably due to the development of the mycelium network between banana and intercrops (Mandou et al., 2015). Similar results were previously obtained by Harinikumar et al., (1990); Ishii et al., (1996) and Li et al., (2009). Lekberg et al., (2010) suggested that when two different species were grown together, they may provide more carbohydrates to the common formed extraradical mycelium and hence increase growth of intraradical mycelium and formation of arbuscules. Arbuscules are the preferential site of exchange between plant and AMF (Smith and Read, 2008) and can be used as an index of mycorrhizal symbiosis functioning. The arbuscule colonization was higher in banana groundnut pairs in comparison to banana sweet potato intercropping system. Van der Leken et al., (2008) demonstrated that although most of the banana intercrop species are mycotrophic, legumes have a 
higher AMF dependency than non leguminous crops. The root architecture of groundnut revealed the absence of root hairs, suggesting that this species is dependant to AMF for nutrient absorption in the soil (Krishna and Bagyaraj, 1984). However, increase in root colonization was not correlated with increase growth probably because of the early interspecific competition between groundnut and banana or sweet potato and banana.

In the presence of sweet potato, the growth of banana plantlets was markedly affected. This was probably due to competition for space and nutrients. A number of sweet potato roots reach the maximum 10 to 15 days after planting and root length is greater at 30 days (Hannsuk and Hozyo, 1983). At the end of the experiment root fresh weight of sweet potato was about two times that of banana. When intercropping between two species is established, early interference may involve competitive root effect (Hauggaard and Jensen, 2005) and the intercrop is able to exploit a large total soil volume if the component crops differ in rooting pattern (Hauggaard et al., 2001 b). In our case, the experiment was performed in boxes which limited volume for root exploration and hence facilitated root interaction competition.

The incorporation of legumes crops in an intercropping system was far considered as a productive combination particularly under conditions of limited nitrogen. This is probably because they provide nitrogen $(\mathrm{N})$ to the system and the soil for succeeding crops via symbiotic N-fixation. Previous studies showed beneficial effects of legumes in an intercropping system in terms of growth, yields and nutrient uptake (Revees, 1992; Jensen, 1996 a; Inal et al., 2007; Rahman et al., 2006; Li et al., 2009). In our experiment, no growth increase of banana plantlets was observed in groundnut - banana combination in comparison to banana monoculture. One reason may be the lack of symbiotic $\mathrm{N}$ - fixation since groundnut was not inoculated with rhizobia strains.

The concentration of minerals in banana shoot was also affected by intercrops species. There was no interspecific root interaction between banana and groundnut for $\mathrm{N}$ and $\mathrm{K}$ uptake. Plants were fertilized with osmocote $(\mathrm{N}-\mathrm{P}-\mathrm{K})$ which may provide adequate supply need for these elements as groundnut is less require. However, $\mathrm{P}$ was negatively affected in banana shoot. Groundnut as legume has high phosphorus requirements as it helps in developing better quality seed with high oil content (Mirvat et al., 2006). Also, groundnut needs additional $\mathrm{P}$ for signal transduction and membrane biosynthesis (Ribet and Drevon, 1996). This suggested that there was a competitive root interaction between banana and groundnut for this element. It has also been reported that small amounts of $\mathrm{P}$ were required for bananas growth (Phirke and Mahorkar, 2010). However growth of banana plantlets was not affected in banana - groundnut combination.

As for growth, sweet potato has negative effect on mineral content in banana shoot. $\mathrm{N}$ and $\mathrm{K}$ were significantly reduced in banana shoot in the presence of sweet potato. These elements are very important for potato yield. $\mathrm{N}$ stimulates the growth of aboveground parts. $\mathrm{K}$ influenced the proportion of dry matter diverted to the tuber, so improved tuber number per plant (Bourke, 1985). Hannsuk and Hozyo (1983) observed the differentiation of tuberous roots 20 days after planting. In our case, six weeks after planting, many roots started to be differentiated into tubers, suggesting a great need of $\mathrm{K}$ for cambial activity in tuberous roots. 
Table.1 Influence of intercropping on mycorrhizal root colonization of banana, groundnut and sweet potato.

\begin{tabular}{llll}
\hline Treatment & Hyphae (\%) & Arbuscules (\%) & Vesicles (\%) \\
\hline $\begin{array}{l}\text { Banana } \\
\text { Banana monocrop }\end{array}$ & $58,33 \pm 4,06 \mathrm{~b}$ & $30,33 \pm 2,43 \mathrm{~b}$ & $23,55 \pm 3,52 \mathrm{a}$ \\
$\begin{array}{l}\text { Banana + } \\
\text { groundnut }\end{array}$ & $75,47 \pm 3,49 \mathrm{a}$ & $51,99 \pm 5,74 \mathrm{a}$ & $32,32 \pm 2,94 \mathrm{a}$ \\
$\begin{array}{l}\text { Banana + sweet } \\
\text { potato }\end{array}$ & $75,33 \pm 3,79 \mathrm{a}$ & $46,77 \pm 5,77 \mathrm{ab}$ & $30,10 \pm 3,90 \mathrm{a}$ \\
& & & \\
\hline $\begin{array}{l}\text { Intercrops } \\
\text { Groundnut }\end{array}$ & $38,66 \pm 3,67 \mathrm{~b}$ & $20 \pm 2,30 \mathrm{~b}$ & $13,55 \pm 1,55 \mathrm{~b}$ \\
$\begin{array}{l}\text { Intercropping } \\
\text { groundnut }\end{array}$ & $52,66 \pm 2,64 \mathrm{a}$ & $33,66 \pm 1,99 \mathrm{a}$ & $26,66 \pm 1,47 \mathrm{a}$ \\
$\begin{array}{l}\text { Sweet potato } \\
\begin{array}{l}\text { Intercropping sweet } \\
\text { potato }\end{array}\end{array}$ & $33,99 \pm 5,20 \mathrm{~b}$ & $19,33 \pm 4,05 \mathrm{~b}$ & $12,88 \pm 1,82 \mathrm{~b}$ \\
& & $30,10 \pm 2,08 \mathrm{a}$ & $22,88 \pm 2,70 \mathrm{a}$ \\
\end{tabular}

Data are means of 6 replicates. Means in the same columns followed by the same letter do not differ according to HDS Tukey test $(\mathrm{P} \leq 0.05)$

Table. 2 Growth of banana influenced by intercropping six weeks after planting (RFW: root fresh weight; SFW: shoot fresh weight; SDW: shoot dry weight)

\begin{tabular}{llllll}
\hline Treatment & Height (cm) & $\begin{array}{l}\text { Pseudostem Leaf area }\left(\mathrm{cm}^{2}\right) \\
\text { diameter } \\
(\mathrm{cm})\end{array}$ & RFW (g) & SFW (g) & SDW (g) \\
\hline
\end{tabular}

\begin{tabular}{|c|c|c|c|c|c|c|}
\hline $\begin{array}{l}\text { Banana } \\
\text { monocrop }\end{array}$ & $10,95 \pm 0,57 \mathrm{a}$ & $1,14 \pm 0,04 \mathrm{a}$ & $138,17 \pm 12,66 \mathrm{a}$ & $7,77 \pm 1,01 \mathrm{a}$ & $24,45 \pm 2,57 \mathrm{a}$ & $1,78 \pm 0,16 a$ \\
\hline $\begin{array}{l}\text { Banana + } \\
\text { groundnut }\end{array}$ & $10,30 \pm 0,37 \mathrm{a}$ & $1,05 \pm 0,06 \mathrm{a}$ & $131,64 \pm 9,00 \mathrm{a}$ & $5,62 \pm 0,66 b$ & $21,64 \pm 2,42 \mathrm{a}$ & $1,81 \pm 0,21 \mathrm{a}$ \\
\hline $\begin{array}{l}\text { Banana + } \\
\text { sweet } \\
\text { potato }\end{array}$ & $8,39 \pm 0,27 b$ & $0,84 \pm 0,03 b$ & $76,30 \pm 5,24 \mathrm{~b}$ & $4,43 \pm 0,46 b$ & $11,87 \pm 1,37 b$ & $0,99 \pm 0,12 b$ \\
\hline
\end{tabular}

Data are means of 10 replicates. Means in the same columns followed by the same letter do not differ according to HDS Tukey test $(\mathrm{P} \leq 0.05)$ 
Table.3 Growth of groundnut and sweet potato influenced by intercropping six weeks after planting (RFW: root fresh weight; SFW: shoot fresh weight; SDW: shoot dry weight). Data are means of 10 replicates. Means in the same columns followed by the same letter do not differ according to HDS Tukey test $(\mathrm{P} \leq 0.05)$

\begin{tabular}{llcl}
\hline \multicolumn{3}{c}{ Growth parameters (g) } \\
\hline Treatment & RFW & SFW & SDW \\
\hline $\begin{array}{l}\text { Intercrops } \\
\text { Groundnut monocrop }\end{array}$ & $2,61 \pm 0,21 \mathrm{a}$ & $20,17 \pm 1,67 \mathrm{a}$ & $2,92 \pm 0,12 \mathrm{a}$ \\
$\begin{array}{l}\text { Intercropped } \\
\text { groundnut }\end{array}$ & $2,31 \pm 0,23 \mathrm{a}$ & $16,90 \pm 1,60 \mathrm{a}$ & $2,80 \pm 0,30 \mathrm{a}$ \\
$\begin{array}{l}\text { Sweet potato } \\
\text { monocrop }\end{array}$ & $9,71 \pm 1,29 \mathrm{a}$ & $60,31 \pm 3,06 \mathrm{a}$ & $6,58 \pm 0,24 \mathrm{a}$ \\
$\begin{array}{l}\text { Intercropped sweet } \\
\text { potato }\end{array}$ & $9,50 \pm 1,06 \mathrm{a}$ & $56,09 \pm 3,11 \mathrm{a}$ & $6,04 \pm 0,30 \mathrm{a}$ \\
\hline
\end{tabular}

Data are means of 10 replicates. Means in the same columns followed by the same letter do not differ according to HDS Tukey test $(\mathrm{P} \leq 0.05)$

Table.4 Nutrient content of shoot of banana influenced by intercropping six weeks after planting.

\begin{tabular}{lcccccc}
\hline Treatment & $\mathrm{N}$ & $\mathrm{P}$ & $\begin{array}{c}\mathrm{K} \\
\mathrm{g} / \mathrm{kg} \mathrm{DW}\end{array}$ & $\mathrm{Ca}$ & $\mathrm{Mg}$ & $\mathrm{Mn}$ \\
\hline $\begin{array}{l}\text { Banana } \\
\text { monocrop }\end{array}$ & $30,10 \pm 1,57 \mathrm{a}$ & $2,25 \pm 0,04 \mathrm{a}$ & $85,56 \pm 1,32 \mathrm{a}$ & $12,46 \pm 1,53 \mathrm{a}$ & $5,66 \pm 0,33 \mathrm{a}$ & $0,16 \pm 0,019 \mathrm{a}$ \\
$\begin{array}{l}\text { Banana }+ \\
\text { groundnut }\end{array}$ & $32,56 \pm 1,29 \mathrm{a}$ & $1,89 \pm 0,07 \mathrm{~b}$ & $84,86 \pm 1,79 \mathrm{a}$ & $11,64 \pm 0,74 \mathrm{a}$ & $5,90 \pm 0,37 \mathrm{a}$ & $0,11 \pm 0 ; 003 \mathrm{~b}$ \\
$\begin{array}{l}\text { Banana + sweet } \\
\text { potato }\end{array}$ & $24,34 \pm 1,51 \mathrm{~b}$ & $2,56 \pm 1,36 \mathrm{a}$ & $76,21 \pm 2,13 \mathrm{~b}$ & $10,35 \pm 0,63 \mathrm{a}$ & $6,17 \pm 0,24 \mathrm{a}$ & $0,09 \pm 0,002 \mathrm{~b}$ \\
& & & & & & \\
\hline
\end{tabular}

Data are means of 5 replicates. Means in the same columns followed by the same letter do not differ according to HDS Tukey test $(\mathrm{P} \leq 0.05)$

It has also been reported that banana requires high quantity of $\mathrm{K}$ and $\mathrm{N}$ for its growth and yield (Phirke and Mahorkar, 2010). The combination of banana and sweet potato in an intercropping system may allow strong root competitive interactions and subsequently growth decrease. For intercropping to be more productive, component crops may differ greatly in growth duration so that their maximum requirements for growth resources occur at different times (Fukai and Trenbath, 1993).

In conclusion, intercropping banana with 
other crops species improve root colonization by arbuscular mycorrhizal fungi. This could be beneficial to banana since it is a perennial crop and may not pass his whole life cycle with companion crops. A long time period for further growth after the harvest of sweet potato should ensure good recovery and full use of available resources. However, the choice of components crops is the key for successful application of the system. These results should be considered with caution since the growth environment was limiting. In natural conditions, minerals are more available because of the constant renewal of the soil solution. Also the soil volume to be explored is infinitely larger. Further studies are thus required to evaluate under field conditions the benefits of increased mycorrhizal root colonization on growth and yield of banana.

\section{Acknowledgement}

The authors would like to thank the GINCO collection at UCL Louvain-la-Neuve, Belgium, for providing mycorrhizal inoculums.

\section{References}

Bourke, R.M. 1985. Influence of nitrogen and potassium fertilizer on growth of sweet potato (Ipomoea batatas) in Papua New Guinea. Field Crops Res., 12: 363-375.

Bücking, H. and Kafle, A. 2015. Role of arbuscular mycorrhizal fungi in the nitrogen uptake of plants: current knowledge and research gaps. Agronomy, 5: 587-612

Chao, T.T. and Sanzolone, R.F. 1992. Decomposition techniques. J. geochemical exploration. 44: 65-106.

Cruz, A.F., Ishiiand, T. and Kadoya, K. 2000. Distribution of vesicular arbuscular mycorrhizal hyphae in the rhizosphere of trifoliate orange and Bahia grass seedlings under an intercropping system. J. Japan. Soc. Hort. Sci., 69: 237-242.

Declerck, S., Devos, B., Delvaux, B. and Plenchette, C. 1994 Growth response of micropropagated banana plants to VAM inoculation. Fruits 49: 103-109.

Fortin, J.A., Plenchette, C., Piché, Y. 2008.

Les Mycorhizes. La nouvelle révolution verte. Editions Multimondes et Quae, $131 \mathrm{p}$.

Fukai, S. and Trenbath, B.R. 1993. Processes determining intercrop productivity and yield of component crops. Field Crops Res., 34(3-4): 247271.

Gianinazzi, S., Gollotte, A., Binet, M. N., van Tuinen, D., Redecker, D. and Wipf, D. 2010. Agroecology: the key role of arbuscular mycorrhizas in ecosystem services. Mycorrhiza, 20: 519-30.

Hannsuk and Hozyo Y. 1983. Sweet potato and yam. Symposium on potential productivity of field crops under different environments, 319-340.

Harinikumar, K.M., Bagyaraj, D.J., Mallesha B.C. 1990. Effect of intercropping and organic soil amendments on native mycorrhizal fungi in an oxisol. Arid Soil Res. Rehab., 4: 193-197.

Hauggaard-Nielsen H. and Jensen, E.S. 2005. Facilitative root interactions in intercrops. Plant Soil 274:237-250

Hauggaard-Nielsen, H., Ambus, P., Jensen, E.S. 2001b. Temporal and spatial distribution of roots and competition for nitrogen in pea-barley intercrops: a field study employing P-32 technique. Plant Soil, 236: 63-74.

Hodge, A., Helgason, T. and Fitter, A. H. 2010. Nutritional ecology of arbuscular mycorrhizal fungi. Fungal Ecol., 3: 267-273 
Inal A., A. Gunes, F. Zhang and I. Cakmak 2007. Peanut/maize intercropping induced changes in rhizosphere and nutrient concentrations in shoots. Plant Physiol. Biochem., 1-7 doi:10.1016/j.plaphy.2007.03.016

Ishii, T., Shrestha, Y.H. and Kadoya, K. 1996. Effect of sod culture system of bahia grass (Paspalum notatum Flügge.) on vesicular - arbuscular mycorrhizall formation of Satsuma mandarin trees. Proc. Int. Soc. Citricul., 2: 822-824.

Jensen, E.S. 1996a. Grain yield, symbiotic $\mathrm{N} 2$ fixation and interspecific competition for inorganic $\mathrm{N}$ in peabarley intercrops. Plant Soil, 182: 2538.

Koske, R.E. and J.N. Gemma. 1989. A modified procedure for staining roots to detect VA mycorrhizas. Mycol. Res., 92, 486-505.

Krishna, K.R. and D.J. Bagyarj. 1984. Growth and nutrient uptake of peanut inoculated with the mycorrhizal fungus Glomus fasciculatum compared with non-inoculated ones Plant and Soil 77: 405-408.

Lekberg, Y., Hammer, E.C. and Olsson, P.A. 2010. Plants as resource islands and storage units - adopting the mycocentric view of arbuscular mycorrhizal networks. FEMS Microbiol. Ecol., 74: 336-345.

Lemeilleur, S., Temple, L. and Kwa, M. 2003. Identification des systèmes de production du bananier dans l'agriculture urbaine et périurbaine de Yaoundé. InfoMusa, 12(1): 13-16.

Li Y., W. Ran, R. Zhang, S. Sun and G. Xu 2009. Facilitated legume nodulation, phosphate uptake and nitrogen transfer by arbuscular inoculation in an upland rice and mung bean intercropping system. Plant Soil, 315:,285-296

Mandou, M.S., Mvondo Ze, A., Etoa, F.X. and Declerck, S. 2015. Effects of extraradical mycelium network of an arbuscular mycorrhizal fungus on the growth of banana plantlets. J. Plant Biol. Res., 4(1): 22-32.

McGonigle, T.P., Miller, M.H., Evans, D.G., Fairchild, G.L., Swan, J.A. 1990. A new method which gives an objective measure of colonization of roots by vesicular-arbuscular mycorrhizal fungi. New Phytologist, 115, 495-501.

McIntyre, B.C., Gold, I., Kashaija, H., Ssali, Night, E. and Bwamiki, D. 2001. Effects of legume Intercrops on soil borne pests, biomass, nutrients and soil water in banana. Biol. Fertil. Soils, 34(5): 342-348.

Mirvat, E., G., Magda, G., Mohamed, H. and Tawfik, M.M. 2006. Effect of Phosphorus Fertilizer and Foliar Spraying with Zinc on Growth, Yield and Quality of Groundnut under Reclaimed sandy Soils. J. Appl. Sci. Res., 2(8): 491-496.

Nasri, R., Kashani, A., Barary, M., Paknejad, F. and Vazan, S., 2014. Nitrogen uptake and utilization efficiency and the productivity of wheat in double cropping system under different rates of nitrogen. Int. $J$. Biosci., 4(4): 184-193

Ouma, G. and Jeuto, P. 2010. Sustainable horticultural crop production through intercropping: The case of fruits and vegetable crops: A review. Agric. Biol J.N. Am., 1(5): 1098-1105

Ouma, G., 2009. Intercropping and its application to banana production in East. Africa: a review. J. Plant Breed. Crop Sci., 1: 13-15

Pelzer, E., Bedoussac, L., Hellou ,G., Jeuffroy, M.H., Métivier, T., et Naudin, C. 2014. Association de cultures annuelles combinant une légumineuse et une céréale : retours d'expériences d'agriculteurs et 
analyse. Innovations Agronomiques 40: 73-91.

Phirke, N.V. and V.K. Mahorkar. 2010. Sustainable Banana (Musa spp.) Production in the Tapi Basin: Khandeshi Farmer's Livelihood Proc. IC on Banana \& Plantain in Africa (Eds. T. Dubois et al.) Acta Hort., 879: 517-525.

Rahman, M., ZRahman, M.H., Haqu, M.E., Kalar, M.H. and Naber, S.L. 2006. Banana-based intercropping system in Northern part of Bangladesh. $J$. Agron., 5(2): 228-231

Reeves, M. 1992. The role of VAM fungi in nitrogen dynamics in maize-bean intercrops. Plant Soil, 144: 85-92.

Ribet, J. and J.J. Drevon. 1996. The phosphorus requirement of $\mathrm{N}_{2}$ fixing and urea-fed Acacia mangium. New Phytol., 132: 383-390.

Schüssler, A., Schwarzott, D. and Walker, C., 2001. A new fungal phylum, the Glomeromycota: phylogeny and evolution. Mycol. Res., 105: 14131421.

Sieverding, E. and Leihner, D.E. 1984. Influence of crop rotation and intercropping of cassava with legumes on VA mycorrhizal symbiosis of cassava. Plant Soil, 80: 143-146.

Smith, S.E. and Read, D.J. 2008. Mycorrhizal symbiosis. New York, NY, USA: Academic Press.

Van der Veken L, P. P.Win, A. Elsen, R. Swennen and D. De Waele. 2008. Susceptibility of banana intercrops for rhizobacteria, arbuscular mycorrhizal fungi and the burrowing nematode Radopholus similis. Appl. Soil Ecol., 40: 283-290.

Vierheilig, H., Coughlan, A.P., Wyss, U. and Piche, Y. 1998a. Ink and vinegar, a simple staining technique for arbuscular-mycorrhizal fungi. Appl. Environ. Microbiol., 64: 5004-5007.

Vos, C., Tesfahun, A.N., Panis, B., De Waele, D., Elsen, A. 2012b. Arbuscular mycorrhizal fungi induce systemic resistance in tomato against the sedentary nematode Meloidogyne incognita and the migratory nematode Pratylenchus penetrans. Appl. Soil Ecol., 61: 1-6.

Willey, R.W. 1979a. Intercropping - Its importance and research needs. Part 1. Competition and yield advantages. Field. Crop. Abstr., 32 : 1-10.

\section{How to cite this article:}

Marie Solange Mandou, Souleymanou Adamou, Dieudonné Nwaga and François-Xavier Etoa. 2016. Intercrops Influence Mycorrhizal Symbiosis Development, Growth and Nutrient Uptake of Banana. Int.J.Curr.Microbiol.App.Sci. 5(12): 84-94. doi: http://dx.doi.org/10.20546/ijcmas.2016.512.010 